\title{
РИТОРИКА УКРАЇНЦІВ: ПОРУШЕННЯ НОРМИ ЯК МОВНА ГРА
}

\author{
ТЕТЯНА КОСМЕДА
}

Дрогобицький державний університет ім. І. Франка, Дрогобич - Україна Університет імені Адама Міцкевича, Познань - Польща

\author{
RETORYKA UKRAIŃCÓW: \\ NARUSZENIE NORMY JAKO GRA JĘZYKOWA
}

TETIANA KOSMEDA

Państwowy Uniwersytet Pedagogiczny w Drohobyczu, Drohobycz — Ukraina Uniwersytet imienia Adama Mickiewicza, Poznań - Polska

STRESZCZENIE. W artykule rozpatrywana jest retoryczna gra językowa, wykorzystywana tradycyjnie, ale aktywnie stosowana również w języku współczesnym. Zaprezentowany został status niniejszego środka wyrazu, mechanizm jego tworzenia i rodzaje.

\section{RHETORIC OF THE UKRAINIANS: VIOLATION OF NORM AS A LANGUAGE GAME}

\section{TETIANA KOSMEDA}

Drohobych Ivan Franko State Pedagogical University — Ukraine Adam Mickiewicz University in Poznań, Poznań, Poland

ABSTRACT. The article deals with rhetoric way of language game that has its tradition of use and is spread in modern speech. The status of image means, the mechanism of its creation, its types have been analyzed.

$\prod$ очаток XX сторіччя - це не лише хронологічне поняття, але й структура, що відображає стан сучасного суспільства і людини у ньому. Аксіомою стало положення про те, що довкілля відображається в мові, зокрема це виражається у діяльності мовної особистості крізь призму іiї мовної свідомості. Актуальними проблемами лінгвістики є вивчення людини-мовця, вияв мовної особистості в багатоаспектному просторі мови. Риторика ж кожної епохи має відмінні риси.

Характерною рисою сучасної риторики є мовна гра. Однак лінгвістичний статус названого явища чітко не визначено, хоч про нього багато пишуть, зокрема такі мовознавці, як Н. Арутюнова, Т. Булигіна, Т. Гридіна, О. Земська, В. Зірка, У. Канторчик, В. Костомаров, В. Санніков, Л. Синельникова, О. Тараненко, О. Тимчук, О. Халіман, А. Цонєва, Д. Шмельов, А. Щербина, Н. ЯнкоТриницька та ін.

Аналізуючи сучасний мовний простір, науковці зауважують, що в моду загалом і в мовну зокрема, ввійшов стиль „гранж” (grunge fashion) - одягатися як можна гірше, породжений бажанням бути оригінальним, бажанням „побешкетувати”, використовуючи мовні засоби. Стиль „гранж” виявляється саме в активному поширенні мовної гри. 
Відомо, що поняття мовна гра у парадигму гуманітарних знань увів Л. Вітгенштейн у „Філософських дослідженнях”; мовну гру визначали як один із видів прагматичної діяльності, тобто її вивчали насамперед у філософському аспекті. Згодом цим явищем логічно зацікавилися й лінгвісти, оскільки воно має відповідне мовне вираження. У радянському мовознавстві, до речі, це явище також активно досліджували: ним цікавилися В. Виноградов, А. Гвоздєв, Д. Розенталь, Г. Солганик, Д. Шмельов та ін. Сучасний російський мовознавець В. Санніков зауважує, що сфера використання мовної гри в лінгвістичних дослідженнях виявляється досить обмеженою - це насамперед джерело ілюстрацій для характеристики явищ омонімії і багатозначності ${ }^{1}$.

Безумовно, дослідники пов'язують мовну гру з поняттям експресивності, адже експресивність - це зображально-виразна якість мовлення. Образності, експресивності досягають найчастіше, використовуючи переносне значення слова. Однак переносне значення вирізняється саме тим, що воно виникає внаслідок незвичної предметної віднесеності слова, яка викликана потребою дати відповідну характеристику предмету, а не просто номінувати його. Експресивні можливості мовної гри — це можливості порушення очікуваного, які можна кваліфікувати не як порушення закріпленої форми для мовного вираження довкілля, а як більш чи менш творче вираження варіантів, що дає змогу краще донести логічну й емоційну інформацію до тих, хто эï сприймає.

Очевидно, в 60-90 роки XX сторіччя мовну гру розглядали виключно у межах лексичного мовного рівня, передусім як каламбур. Таке вузьке розуміння виокремленого явища відображено у більшості сучасних лінгвістичних словників. Термін „мовна гра” у них відсутній, зокрема й у короткому словнику лінгвістичних термінів С. Срмоленко, С. Бибик, О. Тодор (2001). Тут міститься термін „гра слів”, але подається поклик на словникову статтю „Каламбур”. В інших лінгвістичних термінологічних словниках і енциклопедіях взагалі виокремлено лише каламбур, який ототожнюють 3 мовною грою. Це простежуємо, наприклад, і в термінологічній енциклопедії „Сучасна лінгвістика” О. Селіванової (2006). Отже, назріла потреба ввести назване поняття у чинні словники лінгвістичних термінів і належно його описати.

Поняття мовної гри ширше, ніж поняття каламбур, що й зауважують сучасні мовознавці. Болгарська дослідниця Л. Цонєва ${ }^{2}$, яка докладно вивчала це явище, пише, що „мовна гра трактується у широкому розумінні як соціальне відхилення від мовних норм з метою створення певного естетичного (частіше комічного ефекту). При такому підході до мовної гри відносять різні вияви нестандартного, ігрового використання мовних засобів. Важливо відзначити, що традиційне розуміння мовної гри як каламбуру (гри слів) слід уважати обмеженим і несучасним" (переклад мій. — Т. К.) ${ }^{3}$.

Такої ж думки дотримується й В. Санніков, порівн.: „Мовна гра це завжди певна неправильність (чи незвичність), усвідомлена й зумисне допущена мовцем. I за тією оцінкою доволі чітко простежуємо уявлення мовців про норму, про загальні принципи побудови мови і про відхилення від цих принципів, про деякі „дивності” мови”4.

${ }^{1}$ В. 3. Санников, Каламбур как семантический феномен, [в:] „Вопросы языкознания”, 1995, № 3.

${ }^{2}$ Т. А. Космеда, Рецензія. Лиляна Цонева. Езыковата игра в современната публицистика. - Faber, 2000. - 176 c., [в:] „Болгарская русистика”, № 2, 2001, с. 66-67.

${ }^{3}$ Л. Цон ева, Езиковата игра в съвременната публицистика, В. Тырново 2000, с. 162.

${ }^{4}$ В. 3. Санников, Указан. работа, с. 67. 
Польська дослідниця У. Канторчик, як і багато інших учених, також уважає, що ця усвідомлена неправильність, відступ від норми просто необхідні сучасному мовленню, зокрема публіцистичному, оскільки шаблони розвивають лінь мислення й автора, й читача, сприяють пасивному сприйняттю довкілля, що, зрештою, гальмує розвиток особистості, вочевидь, і особистості мовної5.

Сьогодні більшість учених уважають, що мовна гра моделюється за принципом навмисного використання відхилених від норми й усвідомлених на тлі системи і норми явищ. Мовна гра породжує інші, ніж в узусі і нормі, засоби вираження певного змісту, об’єктивує новий зміст при збереженні чи зміні старої форми. Установка на мовну гру знімає суперечності між узуальним і оказіональним використанням мовних одиниць.

Проте залучати людину до мовної гри можна тільки тоді, коли вона оволодіє мовною нормою, нормативними способами комунікації. Мовна гра - це усвідомлене порушення стереотипів. Її слід відрізняти від дитячої словотворчості. Вона базується на відхиленні від стереотипів при усвідомленні непорушності цих стереотипів.

Мовну гру, як зазначалося, справедливо вважають способом увиразнення мовлення, моделювання його свіжості і новизни, порівн.: „Ефект мовної гри 3 пародійним та іронічним відтінками здійснюється шляхом актуалізації мовних знаків різних типів і структур (...) Основний принцип мовотворчості “оновлення" мотивованості словесного знака на тлі автоматизованості стандартної мови".

Отже, щоб викликати увагу читачів (слухачів) необхідно зробити мовлення незвичним, неавтоматизованим. Для цього можна, наприклад, трансформувати добре відомі вирази, вжити оказіоналізми, сумістити різні стилі (наприклад офіційно-діловий і розмовний), обіграти внутрішню форму слова чи усталеного виразу, зіштовхнути різні граматичні категорії і тому под.

Таким чином, мовна гра — це усвідомлене відхилення від літературної норми, адресант обдумано порушує чинні норми 3 конкретною метою, яку адресат повинен дешифрувати.

Мовна гра стала частково й об'єктом „Лінгвістики помилок”, „Патолінгвістики” чи „Девіатології, коли їі розглядають як відхилення від норми, певну аномалію і за певних умов навіть як комунікативну невдачу (,провал”), але в такому разі це вже не мовна гра, а явище іншого порядку. Ф. Бацевич у зв’язку iз цим писав, що кожна діяльність людини, звичайно, супроводжується помилками, це природне явище, яке зазвичай сприймають негативно. Усе розмаїття мовних помилок (описки, ляпсуси, огріхи, неточності, аномалії, комунікативні невдачі і тому подібне) є одночасно важливим джерелом наших знань про мову й інструментом його дослідження ${ }^{7}$. У класифікації, яку пропонує Ф. Бацевич услід за іншими російськими вченими, наприклад Н. Арутюновою, протиставлено дві групи девіацій: усвідомлені і неусвідомлені. Неусвідомлені відхилення мають багато спільного із художніми прийомами, оскільки останні також $€$ порушенням звичного, тобто мовних чи мовленнєвих норм. Але на відміну від прийомів, що служать для розширення, збагачення чи навіть з'яви нових смис-

${ }^{5}$ У. Канторчик, О языке прессы в переломные времена, [в:] Русский язык: исторические судьбы и современность, Международный конгресс, Москва 2001, с. 257.

6 3. С. Санджи-Гаряева, Языковая личность Андрея Платонова через призму языковой игры, [в:] Русский язык: исторические судьбы и современность, Международный конгресс, Москва 2001, с. 146.

7 Див.: Ф. С. Бацевич, Основи комунікативної девіатології, Львів 2000, с. 4-6. 
лів, аномалії, відхилення, помилки стають причиною ускладнення у сприйнятті смислу і комунікації загалом.

Мовна гра - образний прийом, що виконує конкретну прагматичну функцію у тексті, дискурсі, мовленні. Аномалії ж і комунікативні невдачі, з якими іноді плутають мовну гру, є неусвідомленим відхиленням від норми. Аномаліями варто називати лише випадки нерегулярного характеру вияву конкретної форми або конструкції стосовно загального типу, правила. Прагматичні (комунікативні) невдачі необов'язково супроводжуються мовними аномаліями чи прямими помилками у сфері мовленнєвої форми. Вираження може бути лексично, морфологічно, синтаксично і фонетично „правильним”, але одночасно порушені закономірності мовленнєвої діяльності ${ }^{8}$.

У процесі дослідження міського просторіччя науковці також вбачають у ньому сліди мовної гри. Вони вважають, що просторічні слова виконують експресивно-емоційну функцію, крім того, просторіччя протиставляють загальноприйнятим мовним нормам9 ${ }^{9}$ Отож, уживання просторічних слів і виразів можна вважати одним із прийомів створення мовної гри, оскільки це також тягне за собою відхилення від норми.

Про перенесення просторічних елементів у сучасний публіцистичний дискурс пише й I. Соболєва, наголошуючи, що можна розмірковувати про новий, підкреслено знижений тон мови засобів масової інформації, моделі нової мовної поведінки, коли адресант детермінує не лише себе, але й читача 3 відповідною соціальною роллю, ніби робить заявку на обумовлені наперед правила мовної гри ${ }^{10}$. Просторічна периферія може функціонувати у дискурсі як набір орфоепічних, граматичних, семантичних та інших відхилень від норм літературної мови, як спеціально знижений, іноді грубий і фамільярний, спосіб комунікації.

У деяких випадках це свого роду стилізація під мову середовища, яке не володіє літературною мовою. У просторічній периферії простежуються сліди діалектного походження, професійних і молодіжних жаргонів; змішується лексика побутових номінацій; іноземна лексика вживається у перекрученому значенні; змішуються слова і звороти офіційно-ділового й розмовно-побутового вжитку і под.

Просторічна лексика виконує в сучасному мовленні, особливо публіцистичному дискурсі, розмаїття прагматичних функцій. Гра з подібними зниженими одиницями мови - один із найпоширеніших експресивно-виражальних засобів сучасної публіцистики. Різноманітний варіативний ряд просторічних моделей дає змогу адресанту більш яскраво відобразити складний і багатоликий процес сучасного публічного спілкування.

Лінгвісти переконані, що мовні засоби створення експресії в сучасному дискурсі українців передусім пов'язані з відхиленнями від звичайного нормативного мовлення. Такі відхилення набувають стійкого характеру, що дає змогу розмірковувати про особливості сучасної риторики, зокрема й у проекції на мову і стиль ЗМІ як тексту специфічного типу.

3'ява мовної гри зумовлена прагненням по-новому позначити конкретний елемент дійсності, подолати старі стереотипи.

${ }^{8}$ Там само, с. $15-17$.

9 Див.: Л. А. Кудрявцева, Русский язык на Украине: Киевское городское просторечие кониа ХХ столетия, [в:] Русский язык: исторические судьбы и современность, Международный конгресс, Москва 2001, с.191.

${ }_{10}$ Див.: І. О. Соболева, Знижені (позалітературні) мовні засоби в сучасному публічистичному дискурсі, автореф. дис. канд. філол. наук, Сімферополь 2002. 
Отже, сучасний погляд на мовну гру вирізняється широтою, оскільки вона пояснює будь-яке усвідомлене відхилення від норми для досягнення комічного ефекту.

Розмірковуючи про значення цього виразного засобу в комунікації, зауважимо, що кожний мовець, використовуючи мову, переслідує мету досягти запланованого прагматичного ефекту, привернути увагу до форми свого мовлення.

3. Фрейд у свій час також аналізував явище мовної гри, наголошуючи, що одна з важливих функцій мовного жарту — ,задоволення агресивності”. „Масна розмова", яку дуже любить простий люд, в освіченому суспільстві витісняється, відкидається цензурою відповідної культури ${ }^{11}$.

Про це ж пише Д. Ельконін, який пояснює явище мовної гри з огляду на психологічні постулати: „Жарт дає змогу “замаскувати” відповідне повідомлення і завдяки цьому виразити ті смисли, що є під забороною. Мовною грою у широкому розмінні, можна вважати усяку поетичну творчість. Поезія у своїй первинній функції як фактор ранньої культури народжується у грі і як гра. Це освячена гра, але в своїй святості вона все ж залишається на межі деякої брутальності, жарту, розваги. Саме із цим пов'язано факт, що в незрозумілі слова й словосполучення слухачі схильні вкладати брутальний чи непристойний смисл. Мовний жарт дає змогу мовцю порушити важливий принцип спілкування - принцип увічливості, але, разом із тим, маскує і пом'якшує неввічливість"12.

Польський учений Б. Дземідок в умисному відхиленні від норми вбачає лише комічний ефект. У монографії Про комічне він пише: „Деякі дослідники наполягають, що комічним слід уважати будь-яке явище, що відхиляється від норми і тому здається нам недоцільним і дивним. Існує навіть ціла теорія відхилення від норми, основоположником якої є німецький естетик Карл Грос"13. Із цим твердженням погоджується й Л. Житеньова, але при цьому вона зауважує, що „сьогодні ми зіштовхуємося часто не з мовною грою, а із звичайною безграмотністю. Причому різні неправильності потрапляють у засоби масової комунікації, культивуються в них"14. Із цим треба боротися. Для цього потрібна мовна екологічна комісія.

Як бачимо, до цього часу в лінгвістиці відсутнє однозначне визначення мовної гри. Багато вчених, зокрема й Т. Гридіна, порушують питання про те, чи не точніше було б розмірковувати про мовленнєву гру, оскільки це явище $\epsilon$ двовекторним „стосовно мови і мовлення"15. О. Тимчук, наприклад, уважає за доцільне замінити термін „мовна гра” на термін „гра слів” і має своє пояснення цього виразного засобу, порівн.: „Семантико-стилістичне явище гри слів досліджується зазвичай на фонетичному рівні (різні звукові повтори), лексичному (обігрування значень полісемантичного слова, омонімів, паронімів) і меншою мірою на фразеологічному рівні. Однак воно проявляється й на інших мовних рівнях, відповідно і сам термін “гра слів” потрібно приймати дещо умовно, розуміючи під ним також “гру” морфем і загалом структурних елементів слова, морфологічних категорій, синтаксичних одиниць"16. У цьому разі йдеть-

${ }^{11}$ Див.: В. 3. Санников, Указан. работа, с. 58.

12 Д. Б. Эльконин, Психология игр, Москва 1978, с. 262.

${ }^{13}$ Б. Дземидок, О комическом, Москва 1974, с. 33.

14 Л. И. Житенева, ,Газетность” - примета стиля, [в:] “Русская речь”, 1984, № 2, с. 86.

${ }_{15}$ Т. А. Гридина, Языковая игра: стереотип и творчество, Екатеринбург 1996, с.7-10.

16 О. Т. Тимчук, Обігравання структурних елементів слова як семантико-стилістичне явище (морфеміка і словотворення), [в:] “Мовознавство”, 2001, № 2, с. 54. 
ся про формально-смислове обігрування компонентів слова на рівні морфеміки (їх переосмислення без формальних видозмін) і словотвору (з утворенням нових структурних мовних одиниць). Дозволимо собі не погодитися із такою пропозицією, оскільки „гра слів” охоплює лише частину поняття мовна гра.

Отже, порівнюючи два погляди на мовну гру, - традиційний („вузьке” розуміння) і сучасний (,широкий” підхід), можна зробити висновок, що „вузьке” розуміння відсікає значний пласт виразних експресивних засобів. У цьому разі розглядається лише лексика. Однак сучасні дослідження у цій сфері показали, що мовна гра широко репрезентована й на фонетичному, словотвірному, морфологічному й синтаксичному рівнях; іiї можна розглядати крізь призму стилістики й прагматики мови. Зазначене дає право стверджувати, що мовна гра - це умисне, заплановане відхилення від мовних норм із метою створення прагматичного ефекту (естетичного, комічного, сатиричного і под.).

Зауважимо також, що відхилення від норми можуть інколи бути навіть „подвійними”, аплікуючись, умисна помилка накладається одна на одну. Наведемо кілька прикладів, зокрема 3 тексту роману сучасної письменниці Люби Клименко: I в результаті изього акту творіння... постала людина. Але щзо характерно, ие була жінка. Перша жінка! Не просто перша з усього жіноцтва, а взагалі - першіша за чоловіка. Порядковий числівник перший не може утворювати ступенів порівняння.

Але коли мовець, по-перше, порушує норму, використовуючи порядковий числівник - русизм первий, а по-друге, ще до того його ступенює, то маємо дві помилки відразу, наприклад: Грали ми в одному городі (у місті), - задумливо й дивлячись кудись у куток, заговорив він тихо і трагічно. — ... Я, знаєте, підібрав тоді трупку — найпервіший сорт (В. Винниченко).

3 метою наблизити поезію до розмовного мовлення типових українців використовується порушення норми у вигляді мовної гри, що торкається, наприклад, навіть такої поширеної помилки мовлення сучасних українців, як неправильне відмінювання числівника, що яскраво демонструють шістдесятники на прикладі числівника сто, порівн.: „Тоді згадай: десь за стома морями, / десь на крайсвіті мати є твоя...” (В. Стус); „На сто колін перед стома богами / я падаю...” (I. Драч); „Так - я кажу тут лише про людину / $і$ про знамено людини - про усмішку, / взяту від мами Тетяни в полтавському полі, / стома турботами скупану, / стома жсррботами сушену, / стома скорботами замиловану" (I. Драч).

У цьому разі розмиваються межі між мовою й мовленням, точніше кодифікованою літературною мовою і розмовним мовленням, що було характерно для усного й писемного українського мовлення й у давні часи, послідовно виявлялося в художніх текстах і набуло нової традиції відображення в текстах публіцистичних, стало риторичною ознакою сучасного щоденного мовлення українців, що виявляється у всіх видах дискурсу українців.

Отже, мовна гра - це функційно-стилістичне явище, що найповніше виявляється на рівні тексту (дискурсу) і потребує глибокого і докладного вивчення. Його не слід плутати із звичайною безграмотністю.

Видається, що до активного залучення мовної гри у своє щоденне мовлення українців спонукає і характерна риса українського національного характеру - схильність до гумористичного сприйняття дійсності.

Одним із основних постулатів теоретичної лінгвістики традиційно залишається вчення про те, що „мова „живе”, а „жити” — значить змінюватися, не залишаючись у попередньому стані. Мова, як і будь-який інший живий організм, 
постійно розвивається, збагачується, удосконалюється. Представники Празького лінгвістичного гуртка назвали цей процес „ггучкою стабільністю” ${ }^{17}$. Звичайно, прийняті норми через певні проміжки часу потребують перегляду. Сучасна наука про мову зосереджує увагу на особливостях процесу спілкування, породження і сприйняття мовлення, засобах іiї порушення і засобах, що створюють експресію, виразність неповторність мовлення.

Отже, що таке порушення мовної норми — вада мовлення чи його позитивна риса?

Виявляється порушення мовної норми зреалізовується у двох іпостасях. Звичайно, ііі порушення, мотивоване відсутністю відповідної мовної компетенції, призводить до помилок, що характеризує подібне мовлення негативно, але характерною ознакою риторики українців, зокрема й сучасних, $є$ їх схильність до навмисного порушення чинних мовних норм, що створює особливу експресію, виразність, підвищує емоційність, слугує дискурсивним засобом вираження оцінки, привертає увагу слухачів.

Така традиція виникла не сьогодні, адже здавна на неї звертали увагу не лише мовознавці, але й письменники, зокрема О. Пушкін зауважував, що він не любить зразкового мовлення, а надає перевагу „живому мовленню”, що вирізняється деяким відхиленням від норми, зокрема письменник мав на увазі стилістичні норми. Подібне знаходимо й у творця української літературної мови Т. Шевченка, що особливо виражається у його прозових творах, які написані російською мовою.

Цікавою щодо девіацій, пов'язаних із порушенням граматичних норм, $€$ думка Ю. Апресяна про те, що мовна аномалія створюється на базі зіткнення граматикалізованих або граматичних значень між собою з іншими значеннями ${ }^{18}$. Норма - це, як відомо, „сукупність мовних засобів, що відповідають системі мови й сприймаються ії носіями як зразок суспільного спілкування у певний період розвитку мови і суспільства" 19 . Проте саме вишукані, елітарні мовні особистості створюють традицію запланованого, навмисного порушення норм, що дає змогу моделювати мовну гру. Сучасний мовний простір України вирізняється розкріпаченням, у ньому яскраво виявляється „смак епохи” з прагненням до свіжої виразності, відновлення, з бажанням позбутися стерильної i безликої мови. Сучасне мовлення українців вирізнясться яскравістю, у ньому $\epsilon$ i смішне, i дотепне, i драматичне, i, на жаль, навіть агресивне й трагічне. Досягнути такого ефекту носіям мови допомагають виразні мовні засоби, перше місце серед яких посідає, як було зауважено, мовна гра.

Безперечно, основна й найбільш типова форма мовної гри — каламбур. Його виокремлюють усі дослідники мовної гри. Каламбур - один із прийомів створення комічного ефекту, що має давню традицію, але лише в XIX сторіччі починається інтенсивне використання гри слів, відточується техніка створення каламбуру, збагачується палітра відповідних значень.

Отже, сучасна сатира отримала у спадок виразний, добре розроблений прийом каламбурного використання слів. У визначенні каламбуру лінгвісти виявляють єдність: його трактують як гру слів, навмисне створення, зіткнення в одному контексті значень одного й того самого слова чи використання подібності у звучанні різних слів з метою створення комічного ефекту. Подібне розу-

\footnotetext{
${ }^{17}$ В. О. Матези ус, О необходимости стабильности литературного языка, Москва 2003, с. 381.

${ }^{18}$ Ю. Д. Апресян, Тавтологические и контрадикторные аномалии, [в:] его же, Избр. рабоmbl, в 2 тт., Интегральное описание языка и системная лексикография, Москва 1995, т. 2, с. 625.

${ }_{19}$ Украӥнська мова. Енциклопедія, редкол. В. М. Русанівський, О. О. Тараненко та ін., Київ 2007 , c. 438.
} 
міння відображено й у працях В. Саннікова, який зазначає: „Каламбур - це жарт, що базується на смисловому об'єднанні в одному контексті або різних значень одного слова, або різних слів (словосполучень) тотожних, подібних за звучанням" ${ }^{20}$. Як гру слів, що заснована на паронімії, омонімії й полісемії, визначає каламбур, наприклад, Л. Шевчук ${ }^{21}$. Науковці зауважили, що походження слова каламбур є неясним. Частина етимологів поясняють його, як видається, не дуже переконливо, наводячи анекдот про якогось попа з Колонберга. Російська дослідниця Е. Ходакова називає формальні прийоми створення каламбуру: а) багатозначність слів і словосполучень; б) усі види омонімії (повні омоніми, омофони, омографи, омоформи); в) подібність слів і словосполучень за звучанням (так звана парономазія) ${ }^{22}$.

Свою систему засобів створення каламбуру пропонує Л. Шевчук, зауважуючи, що зіткнення різних значень одного й того ж самого слова, змішування омонімов, омофонів, омографів, паронімів у каламбурах розраховано на неочікуваність.

Багато носіїв мови вміло грають зі значенням слів, що прийшли з інших мов, також спостерігаються випадки використання мовної омофонії, коли у процесі зіткнення двох гетерогенних омофонів вдається знайти й актуалізувати одну спільну для них силу. Іноді використовують полісемантичне слово не в двох, як зазвичай прийнято, а зразу в трьох значеннях, тим самим створюючи багатоплановість образного уявлення. М. Жванецький збагатив сатиру синтетичною будовою каламбурів, використовуючи кілька прийомів відразу: полісемію з омофонією, лексичну омонімію з паронімічною атракцією ${ }^{23}$. При цьому Л. Шевчук констатує, що прийом міжмовної омофонії вимагає від письменника, крім блискучого знання мови, особливого лінгвістичного чуття до іншомовного слова.

Проаналізувавши наукові розвідки, що стосуються опису явища каламбуру, розглянувши наявні в мовознавстві визначення цього образного засобу, В. Санніков багато із чим погодився із дослідниками, однак деякі аспекти все ж уточнив, зауваживши, що в наявних дефініціях наголошено на звуковій подібності слів чи словосполучень, що використані для мовної гри, переважно це й, справді, так. Однак інколи каламбур базується не на формальній, звуковій, а на смисловій подібності слів. Це використання псевдо-синонімів чи псевдо-антонімів, тобто слів із різних синонімічних рядів чи різних антонімічних пар, порівн.: На голову впали тітки, дядьки й жінка - світла шатенка з темним минулим (В. Шкваркін).

У наявних дефініціях каламбуру наголошується, що останній має за мету створення комічного ефекту. Проте перераховані технічні елементи (багатозначність, омонімія, звукова подібність слів і словосполучень) часто використовуються і з іншою метою: Ласка з'їла курей і ласку матері (з журналу). Тут маємо форми іменника ласка (тварина) і ласка (характеристика матері). Зовні це схоже на каламбур, але цей вираз не викликає посмішки: у цьому разі йдеться про силіпсис - „серйозного брата каламбуру”24.

У термінологічних словниках силіпсис визначають як синтаксичне об'єднання двох чи більше однорідних членів, що мають відмінності у граматичному плані. Формально силіпсис схожий на каламбур, однак призначення у них різні: каламбур завжди використовують для досягнення комічного ефекту.

${ }^{20}$ В. 3. Санников, Указан. работа, с. 56.

21 Л. В. Шевчук, Формирование языковых средств комического в современной сатире: традиции и новаторство, автореф. дис. канд. филол. наук, Одесса 1991, с. 13.

${ }^{22}$ Е. П. Ходакова, Каламбур в русской литературе XVIII в., Москва 1968, с. 28.

${ }_{23}^{23}$ Див.: Ю. Д. Апресян, Указан. работа, с. 13.

${ }^{24}$ В. 3. Санников, Указан. работа, с. 56-57. 
Порівнюючи ці явища, В. Санніков виокремлює дві структурні відмінності між каламбуром і силіпсисом: у каламбурі простежуємо різке оцінювальне протиставлення елементів, що слугують базою мовної гри. Для каламбуру характерний строгий порядок елементів: спочатку слово, що має позитивне забарвлення, потім те, що має негативну конотацію. Якщо спробувати змінити порядок частин, то гру слів буде збережено, але каламбур зникне. Як і мовна гра загалом, „каламбур - суддя, насмішник, але не підлабузник і не носій компліментів"25. Отже, характерною ознакою мовної гри і каламбуру зокрема як ії найбільш поширеного реалізатора є неочікуваність і гострота, до того ж, основна функція каламбуру - викликати посмішку, додаткові асоціації у слухача (читача), а також допомогти уникнути монотонності оповіді. У кожному каламбурі, крім прямого, буквального смислу, є додатковий — ,іноді доволі вбогий, іноді дуже багатий, причому різний для різних видів каламбуру" ${ }^{26}$. В. Санніков зосередив увагу на цій характеристиці і розробив семантичну класифікацію каламбуру.

Оскільки основою каламбуру є гра слів (зазвичай тотожних чи подібних за звучанням), то базою семантичної класифікації каламбуру став характер семантичних зв'язків між словами, на базі яких моделюється мовна гра. В. Санніков виділив три великі групи каламбуру, деякі з них поділяються на підгрупи: 1) сусіди; 2) маска; 3 ) сім'я. Дослідник наголошує, що ці найменування — тільки ярлики, мітки, зручні під час розгляду доволі складних явищ.

Проте класифікація мовної гри на сьогодні не завершена, оскільки не враховано важливий чинник функціонування на одній території двох чи кількох мов, що також може лежати в основі моделювання мовної гри. Про це явище частково вже йшлося, однак у просторі мовлення українців виокремлюються й інші факти.

На території України, як відомо, тривалий час поширеним залишається явище двомовності — українсько-російське й російсько-українське. У цій статті не будемо оцінювати цей факт $з$ огляду на теорію соціолінгвістики. Проте саме це явище дає змогу породжувати в мовному просторі України різні види мовної гри, що грунтуються зокрема і на зіткненні міжмовних омонімів, паронімів, окремих значень багатозначних слів, що має відповідну часову тривалість. Саме названі причини, що породжують відповідний каламбур, лежать в основі, наприклад, таких анекдотів, що активно поширені в комунікації українців:

Когда и где мы встретимся? — питає російськомовний мешканець Украӥни.

Йому відповідають українською: - Незабаром.

Реакиія російськомовного: - Конечно не за баром, а в баре, но когда?

Чи:

Приїхав російськомовний мешканещьв зі Сходу Украӥни в гості на Різдво на Захід Украӥни. Йому сказали: зайдете в будь-яку хату, привітаєтесь „,Христос рождається”, тоді Вас і нагодують, і напоять. Так $і$ зробив гість, а йому у відповідь — „Славимо його”. Гість ледве втік.

В останньому прикладі каламбур змодельовано на суржиковому варіанті вимови української лексеми, порівн.: славімо - зловімо.

Каламбур моделюють також на основі комунікативних девіацій, пов'язаних iз відсутністю знання фатичних норм комунікації, що пов’язані з релігійними святами зокрема, порівн.: Дзвінок з Заходу України в Крим під час різдвяних свят: „Христос рождається”. Мовчання. Далі відповідь: ”И Вам того же”.

\footnotetext{
${ }^{25}$ Там же, с. 57.

${ }^{26}$ И. П. Лыса кова, Язык газеты: соииолингвистический аспект, Ленинград 1981, с. 85.
} 
Основою створення каламбуру може бути й факт відсутності збігу у граматичних формах слів споріднених української і російської мов, наприклад наведемо анекдот, побудований на маніпуляції значень іменника pluralia и singularia tantum: у російській мові іменник грудь має лише форму однини, а український його еквівалент, навпаки, - тільки множину. Виник анекдот: Українські жінки дуже відрізняються від росіянок, бо в них груди, а в росіянок одна „грудъ”.

В останній час унаслідок того, що державні службовці високого рангу зобов'язані володіти українською мовою як мовою державною, з'явився новий спосіб репрезентації мовної гри, побудований на прийомі стилізації неправильної вимови, порушення мовної норми, що призводить до з'яви омонімічних форм. Так, наприклад, М. Азаров допускає в своєму українському мовленні багато помилок, пов'язаних із недосконалим знанням української мови, впливом на його українське мовлення російської мови, зокрема він не завжди розрізняє позиції чергування О - I у закритих складах (на зразок: кінь - коня, віл вола і под.). Унаслідок цього з'явилася мовленнєва помилка під час вимови слова кровососи, що прозвучало, як кровосісі. Це явище стало чинником породження цілої серії каламбурів, побудованих на маніпуляції цього порушення норми. Креативність українців виявилася у тому, що в Інтернеті з'явилися відповідні фотографії оголених дівчат, груди яких були зафарбовані червоною фарбою. Крім цього, зазначений мовний прийом став основою стилізації мовлення держслужбовців для їхньої негативної характеристики.

Отже, в умовах українсько-російського (російсько-українського) білінгвізму поширені факти моделювання мовної гри, що базуються на каламбурі та деяких інших мовних образних засобах. Констатуємо давню традицію маніпулювання граматичними мовними засобами, порушення мовних і комунікативних норм, що пов'язано з відсутністю відповідного виду компетенції - мовної, комунікативної, прагматичної, культурологічної, однак з'являються й нові тенденції, де мовна гра проектується на володіння тією чи тією мовою загалом, на засудження суржикового мовлення. Естрадний актор, відомий під псевдонімом Вєрка Сердючка, репрезентуючи суржикове мовлення, висміює цей факт.

Художнє мовлення М. Гоголя, що базується на використанні у російськомовному тексті вкраплень з української мови, як відомо, породило його неповторний стиль, що репрезентував неповторність України. У його тексті відсутній будь-який негатив. Має місце лише позитивна конотація.

Проте в сучасному українському мовному просторі, зокрема на естраді, в театрі, мультиплікації та кінематографі з'явилася тенденція, коли негативні персонажі розмовляють суржиком чи російською мовою. Наприклад, у задумі режисера А. Приходька під час постановки драми-фейерії Лесі Українки Лісова nicня (Львівський молодіжний академічний театр імені Леся Курбаса) мати Лукаша, Килина і сам Лукаш у час, коли він розлучився із Мавкою, розмовляють суржиком. Таке саме явище простежуємо й у російському мистецькому мовному просторі, але там негативні персонажі розмовляють українською мовою.

Таким чином, сам факт володіння російською чи українською мовами інколи стає чинником породження мовної гри, репрезентації відповідного виду оцінки, передусім негативної.

У публіцистичному й художньому мовленні активно використовуються варваризми, макаронічне мовлення, засноване на використанні елементів російської мови також переважно для репрезентації негативної оцінки.

Думаю, що зазначений факт потребує глибокого осмислення. В його основі, безперечно, екстралінгвальні чинники. 